\title{
Effect of gossypol on the motility and metabolism of human spermatozoa
}

\author{
K. Wichmann, K. Käpyaho, R. Sinervirta and J. Jänne \\ Department of Biochemistry, University of Helsinki, SF-00170 Helsinki 17, Finland
}

\begin{abstract}
Summary. Gossypol, a polycyclic compound isolated from cotton seeds, had a dosedependent inhibitory effect on human sperm motility. The drug also inhibited powerfully fructolysis and glycolysis by human spermatozoa. Both lactate and $\mathrm{CO}_{2}$ formation from the ${ }^{14} \mathrm{C}$-labelled sugars was inhibited, and the prevention of $\mathrm{CO}_{2}$ formation from $\left[1-{ }^{14} \mathrm{C}\right]$ pyruvate and $\left[2-{ }^{14} \mathrm{C}\right]$ pyruvate by gossypol indicated a direct effect on the tricarboxylic acid cycle. Repeated washing of the sperm cells after gossypol pretreatment failed to abolish the inhibitory effect on $\mathrm{CO}_{2}$ production. The profound disturbances of the sperm energy metabolism induced by gossypol were also reflected by a striking fall of the sperm ATP content. Gossypol had little effect on glucose utilization by minces of human vaginal mucosa, indicating the specificity of gossypol.
\end{abstract}

\section{Introduction}

Gossypol (2,2'-binaphthalene-8, $8^{\prime}$-dicarboxaldehyde-1, 1',6,6',7,7'-hexahydroxy-5,5'-diisopropyl$3,3^{\prime}$-dimethyl), a phenolic compound containing two aldehyde groups, has been reported to exert a marked antifertility effect in males (National Coordinating Group on Male Infertility Agents, 1978). The mechanism of action of this compound is not known, but systemic administration of the drug to male rats results in early indications of disturbed spermatogenesis, although the onset of the antifertility effect is slow (2-4 weeks: National Coordinating Group on Male Infertility Agents, 1978). Electron microscopic examination of gossypol-treated rats revealed morphological changes in the spermatids, such as acrosomal fragmentation and damage to the mitochondrial sheath.

Evidence has also been presented indicating that gossypol does not preferentially accumulate in the testicular tissue: the concentration of the drug in the testis was not more than one third of that found in the liver (National Coordinating Group on Male Infertility Agents, 1978). Spermatids appear to be especially vulnerable to the compound, since no structural changes were observed in the Leydig cells in the gossypol-treated animals.

The effects of gossypol are, however, not restricted to different phases of spermatogenesis. It has been reported to inhibit several enzymes of the tricarboxylic acid cycle (Tso, Lee \& Tso, 1982; Montamat et al., 1982), LDH isoenzyme X (Lee, Moon, Yan \& Chen, 1982), segments of electron transport chain (Tso \& Lee, 1982), and glutathione S-transferase (Lee \& Malling, 1981), and to uncouple respiratory chain and oxidative phosphorylation (Abou-Donia \& Dieckert, 1974). The ATP concentration of rat epididymal spermatozoa correlates closely with the sperm motility (Ke \& Tso, 1982).

Pösö, Wichmann, Jänne \& Luukkainen (1980) reported that low concentrations of gossypol exert a direct effect on mature (motile) human spermatozoa as indicated by a striking decrease in sugar degradation and gradual loss of motility. We have now expanded these studies of the effects of gossypol on the metabolism of human spermatozoa. 


\section{Materials and Methods}

Semen samples. Semen was obtained from a local clinical laboratory performing semen analyses. Based on motility (50-80\%) and morphology, apparently normal, pooled semen samples were first diluted (1:1) with a Ringer solution containing $123 \mathrm{~mm}-\mathrm{NaCl}, 5 \mathrm{~mm}-\mathrm{KCl}, 1 \mathrm{~mm}-\mathrm{MgSO}_{4}, 500$ i.u. benzylpenicillin $/ \mathrm{ml}$ and $0.2 \mathrm{mg}$ streptomycin sulphate $/ \mathrm{ml}$ and buffered with $37 \mathrm{mM}-\mathrm{Tris}-\mathrm{HCl}$, pH 8.0 (Murdoch \& White, 1968; Eliasson, 1971). The spermatozoa were separated from the seminal plasma by low-speed centrifugation $(75 \mathrm{~g}, 10 \mathrm{~min})$ at room temperature, washed twice with the Ringer solution and suspended in the same solution at a cell density of $50-100 \times 10^{6} \mathrm{cells} / \mathrm{ml}$.

Chemicals. [U-14 C]Fructose (sp. act. $283 \mathrm{Ci} / \mathrm{mmol}$ ), [U-14 C]glucose (sp. act. $333 \mathrm{mCi} / \mathrm{mmol}$ ), [1${ }^{14} \mathrm{C}$ pyruvic acid, sodium salt (sp. act. $17 \cdot 3 \mathrm{mCi} / \mathrm{mmol}$ ) and $[2-14 \mathrm{C}]$ pyruvic acid, sodium salt (sp. act. $16 \cdot 6 \mathrm{mCi} / \mathrm{mmol}$ ) were all purchased from the Radiochemical Centre (Amersham, Bucks, U.K.). Other chemicals were of analytical grade of purity. Gossypol, a gift from Dr C. Chang (Population Council), was dissolved in absolute ethanol. The same amount of ethanol was used as the vehicle control. The purity of the gossypol preparation used was verified with both gas-liquid chromatography and mass spectrometry.

Determination of sperm motility. The spermatozoa were washed twice with the Ringer solution containing $0.5 \%$ human plasma albumin, and the washed cells were suspended in the same solution. The suspension was preincubated in test tubes for $15 \mathrm{~min}$ at $37^{\circ} \mathrm{C}$. Thereafter, different concentrations of gossypol were added, and samples were taken at successive times for motility determination by microscopic observation. The sample was diluted with Ringer solution, 100 cells were counted and the proportion of motile cells was estimated. The person performing the counting procedure was unaware of the order of the samples.

Degradation of glucose and fructose. Washed spermatozoa $\left(100 \times 10^{6}\right.$ cells $\left./ \mathrm{ml}\right)$ were preincubated in Ringer solution ( $\mathrm{pH} 8.0$ ) at $37^{\circ} \mathrm{C}$ with various additions (see 'Results') for $20 \mathrm{~min}$ unless otherwise indicated. Then $0.5 \mu \mathrm{Ci}\left[\mathrm{U}-{ }^{14} \mathrm{C}\right]$ glucose (final concentration $0.2 \mathrm{mM}$ ) or $0.5 \mu \mathrm{Ci}$ $\left[\mathrm{U}-{ }^{14} \mathrm{C}\right]$ fructose (final conc. $0 \cdot 2 \mathrm{mM}$ ) were added, the tubes were capped tightly, and the incubation was continued for $30 \mathrm{~min}$ with gentle shaking. The final incubation volume was $0.4 \mathrm{ml}$. The $\mathrm{CO}_{2}$ evolved was collected in $0.1 \mathrm{ml}$ Soluene (Packard Instrument Company) and counted for radioactivity. The reaction was halted by an addition of $0.5 \mathrm{ml} 25 \%(\mathrm{w} / \mathrm{v})$ trichloroacetic acid, and $0.2 \mathrm{ml}$ of the protein-free supernatant solution was used for lactate determination by the method of Hoskins \& Patterson (1968).

Formation of $\mathrm{CO}_{2}$ from pyruvate. Washed spermatozoa $\left(100 \times 10^{6} \mathrm{cells} / \mathrm{ml}\right)$ were preincubated at $37^{\circ} \mathrm{C}(\mathrm{pH} 8.0)$ with additions (see 'Results') for $20 \mathrm{~min}$. Then $0.5 \mu \mathrm{Ci}\left[1-{ }^{14} \mathrm{C}\right]$ pyruvate or [2${ }^{14} \mathrm{C}$ ]pyruvate (final conc. $0 \cdot 1 \mathrm{~mm}$ ) was added, and the incubation was continued for $30 \mathrm{~min}$. The radioactivity liberated was measured as described above.

$A T P$ content of the spermatozoa. Washed spermatozoa $\left(100 \times 10^{6}\right.$ cells $\left./ \mathrm{ml}\right)$ were incubated at $37^{\circ} \mathrm{C}$ (pH 8.0) with additions (see 'Results') in a final volume of $0.4 \mathrm{ml}$. For ATP assay the sperm suspension was diluted with water to a final density of $2 \times 10^{6} \mathrm{cells} / \mathrm{ml}$, and the cell ATP content was measured with a Lumac Celltester M1020 (Lumac Systems AG, Basel, Switzerland), according to the manufacturer's application bulletin. In this method, sperm cells are disrupted with a releasing reagent, and then ATP is determined using firefly luciferin-luciferase, which is specific to ATP. An internal ATP standard is used.

Degradation of glucose in vaginal mucosa minces. Minces of fresh human vaginal mucosa ( $50 \mathrm{mg}$ in $0.4 \mathrm{ml}$ Ringer solution) were preincubated for $20 \mathrm{~min}$ at $37^{\circ} \mathrm{C}(\mathrm{pH} 8.0$ ) with $0-100 \mu \mathrm{M}$-gossypol. Then $0.5 \mu \mathrm{Ci}\left[\mathrm{U}-{ }^{14} \mathrm{C}\right] \mathrm{glucose}$ (final conc. $0.025 \mathrm{mM}$ ) was added and the incubation was continued for $30 \mathrm{~min}$. The degradation of glucose was followed as described for the spermatozoa.

\section{Results}

\section{Effect of gossypol on the motility of human spermatozoa}

The gradual immobilization of human spermatozoa in the presence of gossypol is demonstrated in Text-fig. 1. The spermatozoa were also rapidly immobilized in human cervical mucus preparations containing 50-100 $\mu \mathrm{M}$-gossypol (results not shown). 


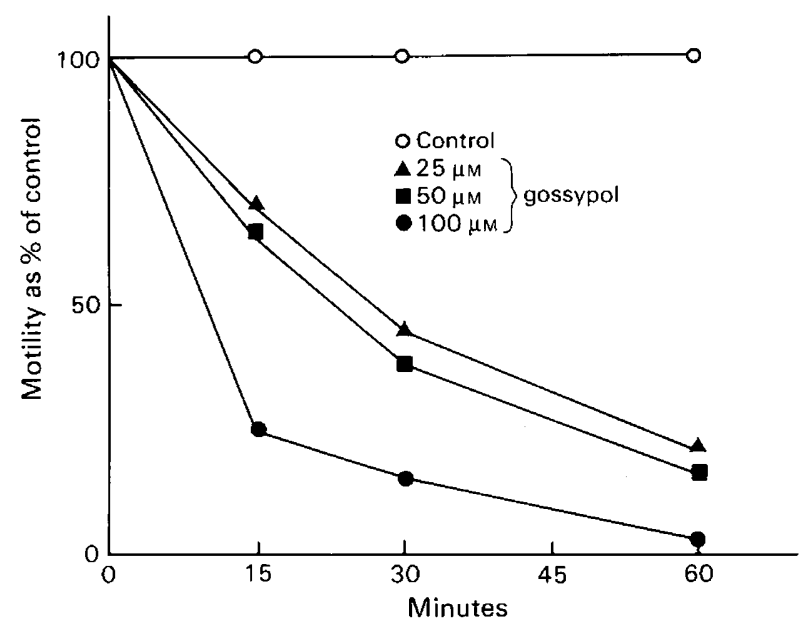

Text-fig. 1. Effect of increasing gossypol concentrations on the motility of ejaculated human spermatozoa. Values are of a representative experiment but were similar in at least 2 other experiments.

\section{Inhibition of sperm fructolysis by gossypol}

When freshly ejaculated spermatozoa were exposed to increasing concentrations $(5-50 \mu \mathrm{M})$ of gossypol, the degradation of radioactive fructose to lactate and $\mathrm{CO}_{2}$ was markedly inhibited (Table 1). The effect was dose-dependent, and $50 \mu \mathrm{M}$-gossypol caused a total inhibition of the fructolytic activity. The degradation of $\left[\mathrm{U}-{ }^{14} \mathrm{C}\right] \mathrm{glucose}$ to lactate and $\mathrm{CO}_{2}$ was similarly inhibited, although low gossypol concentrations $(5-10 \mu \mathrm{M})$ appeared to have little effect on the degradation (results not

Table 1. Effect of different gossypol concentrations on human sperm fructolysis

\begin{tabular}{ccccccc}
\hline \multirow{2}{*}{$\begin{array}{c}\text { Gossypol } \\
(\mu \mathrm{M})\end{array}$} & \multicolumn{2}{c}{$\mathrm{CO}_{2}$} & & \multicolumn{2}{c}{$\left[{ }^{14} \mathrm{C}\right] \mathrm{lactate}$} \\
\cline { 2 - 3 } & $\mathrm{pmol} / 10^{6}$ cells & $(\%)$ & & pmol/106 cells & $(\%)$ \\
\hline 0 & $119 \cdot 0 \pm 25 \cdot 3$ & $(100)$ & & $649 \cdot 9 \pm 225 \cdot 1$ & $(100)$ \\
5 & $107 \cdot 2 \pm 25 \cdot 3$ & $(90)$ & & $477 \cdot 7 \pm 202 \cdot 5$ & $(90)$ \\
10 & $45 \cdot 5 \pm 17 \cdot 1$ & $(38)$ & & $142 \cdot 4 \pm 77 \cdot 8$ & $(22)$ \\
50 & $3 \cdot 4 \pm 2 \cdot 1$ & $(3)$ & & $13 \cdot 6 \pm 6 \cdot 9$ & $(2)$ \\
\hline
\end{tabular}

For experimental details see 'Materials and Methods'. The values are means $( \pm$ s.d.) of 4 separate experiments.

Table 2. Effect of gossypol on the formation of carbon dioxide from $\left[1-{ }^{14} \mathrm{C}\right]$ pyruvate and $\left[2-{ }^{14} \mathrm{C}\right]$ pyruvate by human spermatozoa

\begin{tabular}{ccccr}
\hline \multirow{2}{*}{$\begin{array}{c}\text { Gossypol } \\
(\mu \mathrm{M})\end{array}$} & {$\left[1 \cdot{ }^{14} \mathrm{C}\right]$ pyruvate } & $(\%)$ & {$[2-14$ C]pyruvate } & $(\%)$ \\
\hline \multirow{2yyyy}{0}{} & $429 \cdot 1 \pm 188 \cdot 1$ & $(100)$ & $28 \cdot 0 \pm 5 \cdot 3$ & $(100)$ \\
10 & $373 \cdot 6 \pm 149 \cdot 7$ & $(87)$ & $24 \cdot 4 \pm 6 \cdot 3$ & $(87)$ \\
25 & $155 \cdot 5 \pm 108 \cdot 1$ & $(36)$ & $4 \cdot 4 \pm 2 \cdot 2$ & $(16)$ \\
50 & $73 \cdot 4 \pm 87 \cdot 5$ & $(17)$ & $1 \cdot 0 \pm 0 \cdot 3$ & $(4)$ \\
\hline
\end{tabular}

The spermatozoa were exposed to increasing concentrations of gossypol and incubated in the presence of $\left[1-1^{4} \mathrm{C}\right]-$ or $[2-14 \mathrm{C}]$ pyruvate as described in 'Materials and Methods'. The values are means $( \pm s . d$.) obtained from 4 separate experiments. 
shown). The results indicated that gossypol might inhibit some steps of the glycolytic pathway. To study whether the drug had any influence on the reactions of the tricarboxylic acid cycle, gossypoltreated spermatozoa were incubated in the presence of $\left[1-{ }^{14} \mathrm{C}\right]$ pyruvate or $\left[2-{ }^{14} \mathrm{C}\right]$ pyruvate and the formation of radioactive $\mathrm{CO}_{2}$ from these substrates was measured (Table 2). A dose of $10 \mu \mathrm{M}$ gossypol appeared to have little effect on the degradation of either labelled compound, but higher drug concentrations $(25$ and $50 \mu \mathrm{M})$ inhibited profoundly the $\mathrm{CO}_{2}$ evolution, especially from [2${ }^{14}$ C]pyruvate.

Text-figure 2 shows that $50 \mu \mathrm{M}$-gossypol depleted the sperm cells of ATP in $30 \mathrm{~min}$, while the ATP content of the control cells remained virtually unchanged.

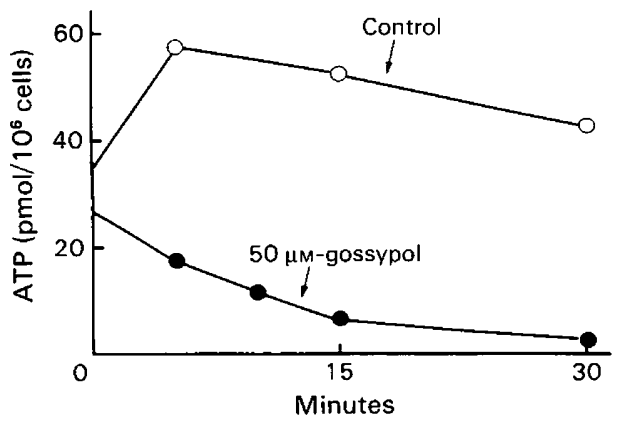

Text-fig. 2. Effect of gossypol on human sperm ATP content. Values are of a representative experiment but were similar in at least 2 other experiments.

\section{Attachment of gossypol to sperm cells}

Spermatozoa were incubated for $20 \mathrm{~min}$ in the presence of increasing (0-100 $\mu \mathrm{M})$ gossypol concentrations. Then the gossypol-containing medium was removed and the cells were washed twice. The formation of $\mathrm{CO}_{2}$ from glucose was determined in a gossypol-free medium. Table 3 shows that removal of gossypol by careful washing after the 20 -min preincubation did not restore the glycolytic activity.

Table 3. Effect of repeated washings on glucose utilization of human spermatozoa exposed to gossypol

\begin{tabular}{ccccc}
\hline & \multicolumn{4}{c}{$\mathrm{CO}_{2}\left(\mathrm{pmol} / 10^{6}\right.$ cells) } \\
\cline { 2 - 5 } $\begin{array}{c}\text { Gossypol } \\
(\mu \mathrm{M})\end{array}$ & $\begin{array}{c}\text { Cells with } \\
\text { gossypol }\end{array}$ & $(\%)$ & Washed cells & $(\%)$ \\
\hline 0 & 69.9 & $(100)$ & 28.1 & $(100)$ \\
25 & 16.6 & $(24)$ & 6.3 & $(23)$ \\
50 & 9.9 & $(15)$ & 2.7 & $(10)$ \\
100 & 2.0 & $(3)$ & 0.5 & $(3)$ \\
\hline
\end{tabular}

The spermatozoa were exposed to increasing concentrations of gossypol for $30 \mathrm{~min}$. Then the formation of $\mathrm{CO}_{2}$ from $\left[{ }^{14} \mathrm{C}\right]$ glucose was measured in the presence of gossypol or, after washing the cells twice with Ringer solution, in a drug-free medium. Values are for a representative experiment but were similar in at least 2 other experiments.

\section{Effect of gossypol on glucose utilization in human vaginal mucosa minces}

Gossypol concentrations (up to $100 \mu \mathrm{M}$ ) that were totally inhibitory to sperm sugar degradation only moderately depressed energy-yielding sugar metabolism in vaginal minces (Text-fig. 3 ). 


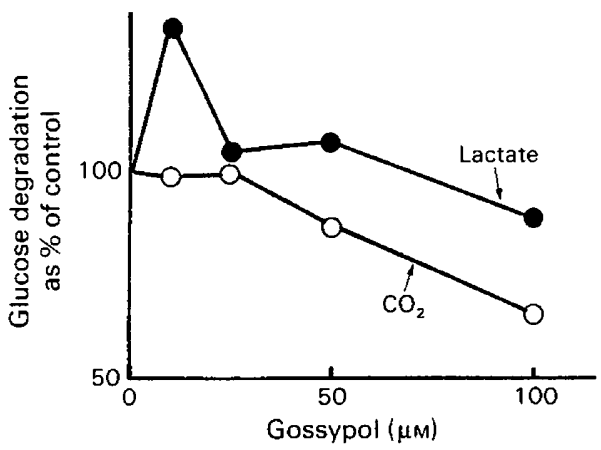

Text-fig. 3. Effect of gossypol on glucose degradation in minces of human vaginal mucosa. The preparations were treated as described in 'Materials and Methods'. The results represent the mean of 2 different mucosal samples.

\section{Discussion}

Ever since the antifertility effect of gossypol was recognized in China, a number of reports have described its effects on spermatogenesis and sperm metabolism. Chronic administration of gossypol to rats leads to mitochondrial and flagellar damage in testicular and epididymal spermatozoa (Hoffer, 1982; Oko \& Hrudka, 1982) and to a decrease of sperm ATP content with a concomitant loss of motility (Ke \& Tso, 1982). Mitochondrial involvement is also implicated by studies suggesting that gossypol may act as an uncoupler of mitochondrial oxidative phosphorylation (Abou-Donia \& Dieckert, 1974), and inhibit lactate dehydrogenase X, an enzyme postulated to participate in a shuttle system transferring $\mathrm{H}^{+}$from cytosol to mitochondria (Gerez de Burgos, Burgos, Montamat, Moreno \& Blanco, 1978).

The present results show that gossypol exerts a profound inhibitory effect on sperm sugar degradation in vitro. Glucose and fructose (Table 1) utilization was totally inhibited in the presence of $50 \mu \mathrm{M}$-gossypol, which is in good agreement with our earlier observation (Pösö et al., 1980). Sperm $\mathrm{CO}_{2}$ production was also inhibited when radioactive pyruvate was used as the substrate (Table 2), suggesting a direct effect of gossypol on the enzymes of the tricarboxylic acid cycle. The results of Tso \& Lee (1981) indicate that gossypol inhibits the sperm respiration rate when succinate is used as the substrate, while a considerably weaker inhibition was observed with malate and pyruvate as substrates. Further, Tso et al. (1982) reported that of several sperm enzymes tested, isocitrate dehydrogenase, succinyl-CoA synthetase and fumarase were inhibited by gossypol at concentrations below $0.1 \mathrm{~mm}$.

Our studies revealed that gossypol strongly inhibits $(80-90 \%)$ the uptake of radioactive fructose, glucose and pyruvate into spermatozoa whose fructolysis was prevented by iodoacetate (results not shown). This makes it very difficult to distinguish a solely membrane effect from a combined membrane and intracellular action. It appears evident, however, that gossypol is able to traverse the cell membrane (Montamat et al., 1982), and the differential effect of gossypol on [1$\left.{ }^{14} \mathrm{C}\right]$ pyruvate and $\left[2-{ }^{-14} \mathrm{C}\right]$ pyruvate degradation (Table 2 ) indicates that processes other than mere uptake are affected by the drug; gossypol also inhibited fructolysis in cell-free extracts (results not shown). Nevertheless, the fact remains that gossypol profoundly disturbs the uptake of glucose (and of fructose), as well as that of pyruvate, into the spermatozoon.

Because of the block in energy production, the sperm ATP concentration decreased rapidly (Text-fig. 2), concomitantly with the loss of sperm motility (Text-fig. 1). The decrease of the ATP level may be caused both by the inhibition of glycolysis and the putative uncoupling of oxidative phosphorylation. The initial rise in the ATP content of the control cells is probably due to transfer of the cells from room temperature (during washing) to $37^{\circ} \mathrm{C}$, which is the incubation temperature. 
Hoffer (1982) indicated that the deleterious morphological effects of gossypol in vivo are specific to spermatozoa, since no changes were observed in the epididymal or vasal epithelium. The results of Text-fig. 3 show that gossypol is also relatively inert in human vaginal mucosa cells. The apparent specificity of gossypol towards spermatozoa could lead to gossypol-based vaginal contraceptives.

\section{References}

Abou-Donia, M.B. \& Dieckert, J.W. (1974) Gossypol: uncoupling of respiratory chain and oxidative phosphorylation. Life Sci. 14, 1955-1963.

Eliasson, R. (1971) Oxygen consumption of human spermatozoa in seminal plasma and a Ringer solution. J. Reprod. Fert. 27, 385-389.

Gerez de Burgos, N.M., Burgos, C., Montamat, E.E., Moreno, J. \& Blanco, A. (1978) A shuttle system for the transfer of reducing equivalents in mouse sperm mitochondria. Biochem. Biophys. Res. Commun. 81, 644-649.

Hoffer, A.R. (1982) Ultrastructural studies of spermatozoa and the epithelial lining of the epididymis and vas deferens in rats treated with gossypol. Archs Androl. 8, 233-246.

Hoskins, D.D. \& Patterson, D.L. (1968) Metabolism of Rhesus monkey spermatozoa. J. Reprod. Fert. 16, 183-195.

Ke, Y.-B. \& Tso, W.W. (1982) Variations of gossypol susceptibility in rat spermatozoa during spermatogenesis. Int. J. Fert. 27, 42-46.

Lee, C.-Y. \& Malling, H.V. (1981) Selective inhibition of sperm-specific lactate dehydrogenase- $X$ by an antifertility agent, gossypol. Fedn Proc. Fedn Am. Socs exp. Biol. 40, 718 .
Lee, C.-Y., Moon, Y.S., Yan, J.H. \& Chen, A.F. (1982) Enzyme inactivation and inhibition by gossypol. Molec. cell. Biochem. 47, 65-70.

Montamat, E.E., Burgos, C., Gerez de Burgos, N.M., Rovai, L.E., Blanco, A. \& Segura, J. (1982) Inhibitory action of gossypol on enzymes and growth of Trypanosoma cruzi. Science, N.Y. 218, 288-289.

Murdoch, R.N. \& White, I.G. (1968) Studies on the metabolism of human spermatozoa. J. Reprod. Fert. 16, 351-361.

National Coordinating Group on Male Infertility Agents (1978) Gossypol, a new antifertility agent for males. Chinese Med. 4, 417-428.

Oko, R. \& Hrudka, F. (1982) Segmental aplasia of the mitochondrial sheath and sequelae induced by gossypol in rat spermatozoa. Biol. Reprod. 26, 183195.

Pösö, H., Wichmann, K., Jänne, J. \& Luukkainen, T. (1980) Gossypol, a powerful inhibitor of human spermatozoal metabolism. Lancet i, 885-886.

Tso, W.W. \& Lee, C.-S. (1981) Variations of gossypol sensitivity in boar spermatozoal electron transport chain segments. Contraception 24, 569-576.

Tso, W.W., Lee, C.-S. \& Tso, M.Y.W. (1982) Sensitivity of various spermatozoal enzymes to gossypol inhibition. Archs Androl. 9, 31-32.

Received 14 February 1983 